\title{
Should Young Professional Buy or Rent a Home?
}

\section{Nor Suzylah Sohaimi}

To Link this Article: http://dx.doi.org/10.6007/IJARBSS/v11-i1/9009

DOI:10.6007/IJARBSS/v11-i1/9009

Received: 11 November 2020, Revised: 06 December 2020, Accepted: 17 January 2021

Published Online: 31 January 2021

In-Text Citation: (Sohaimi, 2021)

To Cite this Article: Sohaimi, N. S. (2021). Should Young Professional Buy or Rent a Home? International Journal of Academic Research in Business and Social Sciences, 11(1), 867-876.

\section{Copyright: (c) 2021 The Author(s)}

Published by Human Resource Management Academic Research Society (www.hrmars.com)

This article is published under the Creative Commons Attribution (CC BY 4.0) license. Anyone may reproduce, distribute, translate and create derivative works of this article (for both commercial and non-commercial purposes), subject to full attribution to the original publication and authors. The full terms of this license may be seen at: http://creativecommons.org/licences/by/4.0/legalcode

\section{Vol. 11, No. 1, 2021, Pg. 867 - 876}

Full Terms \& Conditions of access and use can be found at http://hrmars.com/index.php/pages/detail/publication-ethics 


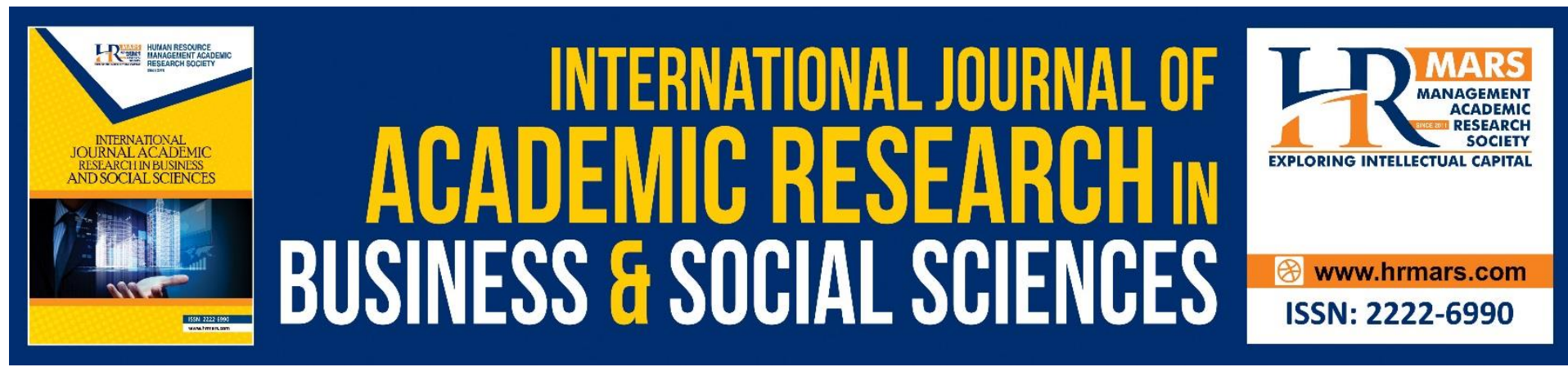

\title{
Should Young Professional Buy or Rent a Home?
}

\section{Nor Suzylah Sohaimi}

Department of Planning and Property Development, School of Government, College of Law, Government and International Studies, Universiti Utara Malaysia, Malaysia.

\begin{abstract}
Housing decisions either buying or renting are always associated with financial affordability. Apart from financial conditions, there are other attributes that might influence a housing decision as both homeownership and renting has its own advantages and disadvantages. This study provides perspective on both housing choices, which presents two research objectives. Firstly, to identify the advantages and disadvantages between buying and renting a home and narrative literature reviews and SWOT analysis were used to obtain this research objective. Second research objective is to identify the housing decision trend among young professional and in-depth semi structured interview methods that have been used and analysed using narrative analysis. Briefly, homeownership offers securing a permanent home with stability in mortgage monthly payment while the renting market tends to increase periodically. However, renting is ideal for households who tend to mobility but households with children prefer homeownership due to its offer neighbourhood stability. This study also found that the young professionals were able to afford buying a home at the age 28 and 29 year old, which they were in the rental market or parental home after the student pathways.
\end{abstract}

Keywords: Young Professional, Housing Affordability, Housing Decision, Housing Pathways, Renting.

\section{Introduction}

Issue related to young professionals' housing affordability have been vastly discussed since 2013 and being a controversial issue and reached a crisis level (Sohaimi, 2017), as most of the new launched residential project in urban area such as Kuala Lumpur reached MYR 500,000 and MYR 1M (Khazanah Research Institute, 2015). Young's housing affordability issue is not merely at local level but the issue acute at global level. Youth Access (2007) found that the young cohort struggles over the housing affordability crisis three times more than other cohorts.

Housing affordability is always associated with monetary principles (Mulliner \& Maliene, 2015; Wilcox, 2003) which is defined as the relationship between housing cost and household income. The price-income ratio (PIR) is the predominant approach to address housing affordability (Jewkes \& Delgadillo, 2010; Linneman \& Megbolugbe, 1992), with allocating $30 \%$ of gross annual income for housing cost considered as housing affordability (Ankhi \& Joy, 2013; Jewkes \& Delgadillo, 2010) while exceeding 30\% is vice versa (Hulchanski, 1995; Jewkes \& Delgadillo, 2010; Linneman \& Megbolugbe, 1992). However, some scholars led by Stone (2006) hold an opponent perspective compared to PIR, where housing 
affordability does not merely consider a household's capability for housing cost, but equally vital, adequacy for household needs. Stone's work is recognised as residual income model (RIM) with measure housing affordability by looking into the association between household expenditure and household income (Hancock, 1993; Sani, 2007; Stone, 2006). Technically, this approach indicates that in order to attain housing affordability, the monthly household income (disposable income) requires a positive amount after pay the monthly housing cost and monthly household expenditure. One important point to distinguish between RIM and PIR is RIM emphases on the concept of 'sufficiency' of the household income for housing cost and household expenditure.

These both approaches are fiscally focused where does not address other housing preferences attributes. In the housing decision, however, young professionals would have other housing preferences besides financial affordability. As mentioned by Ling, Almeida and Wei (2017), financial affordability is equally important with other housing preferences such as sufficient in house quality, location, and size to define housing affordability. In this vein, young professionals might have a choice either for buying or renting a home. Some dwellers have affordability for buying a home but by choice desire for renting and some others have less affordability due to new starting in their career pathways (Olanrewaju \& Tan, 2018). In the local context, renting as a housing choice is less attention compared to homeownership. Therefore, this study provides perspective on both housing choice, renting and homeownership.

\section{Methodology}

This study addresses two research objectives. Firstly, to identify the advantages and disadvantages between buying and renting a home. Narrative or traditional literature review analysis and SWOT analysis were used to attain this research objective. Initially, information regarding the advantages and disadvantages of renting and buying collected from reputable journals and reports. Then, all points of information has split into their strengths, weaknesses, opportunities and threats over the SWOT analysis. Briefly, first research objective is relying on the secondary data. Meanwhile, for the second research objective, relying on primary data, which in-depth semi-structured interview was conducted among three young professionals. The interview information has analysed using narrative analysis to answer the research question "What is the housing decision trend among young professionals?".

The respondents have been obtained from recognised professional bodies in Malaysia and all respondents have been selected by purposive sampling. The criteria of respondents in this study are (i) aged between 25 and 35, (ii) graduate with at least Bachelor's degree and working or living in Greater Kuala Lumpur (Greater KL). Greater KL experiences urbanisation, for example Kuala Lumpur and Putrajaya have achieved $100 \%$ of urbanisation and Selangor about $91.4 \%$ of urbanisation (Department of Statistics, 2010). Hence, undeniably that Greater $\mathrm{KL}$ has been chosen among young working households include young professionals.

\section{Analysis}

\section{1) Advantages and disadvantages of buying and renting a home.}

A housing decision, either to rent or buy, generally relied on similar economic and social aspects of independence with other factors. Interdependency in housing decisions arise when structural, social or economic catalysts of one decision influence another decision, for example, a household makes a decision to rent or buy are based on family situation and household structure, disposable income and household expenditure and mobility factors 
(Silver, 1988). The decision to rent or own falls on the consumption side of the multi-faceted nature of housing (Smith in Hargreaves, 2002:3). Generally, homeownership is considered as a top priority for all social levels and a major goal for all Malaysian. However, undoubtedly that renting a house is becoming a trend and acceptable, as the cost of living is increasing and depleting a person's disposable income and also due to insecure jobs, therefore renting a house is beginning to make more sense rather than homeownership (Fraser, 1992).

Privacy is one of the housing preferences in making a housing decision and considered the leading goal of homeownership. The household can renovate based on their preferences, which is a benefit of homeownership that renters missed. The stability for monthly mortgage payment would be one of the housing decisions for homeownership compared to renting. Homeownership involves a fixed-rate mortgage which the debtor allocates the same monthly amount for principal and interest rate until the mortgage is paid off, but rents are vice versa, it could increase periodically based on lease renewal(McCabe, 2016). In other words, monthly housing costs are predictable for homeownership based on a fixed rate mortgage, therefore the homeowner can plan their finance over a long period of time unlike the unpredictability of renting. In the vein, the property tax, interest rate and mortgage insurance might fluctuate and change monthly payments, but it is not frequently if compared to rent increase.

The housing decision on homeownership is also driven by the reason for neighborhood stability. Neighborhood refers to an area where communities live together (Sean and Hong, 2014) and have reciprocal action among communities, and provides a pleasing view and environment, public space for gathering and mutual support (Jayantha and Ming, 2016). A study conducted by Rohe and Stewart (1996) found that a positive relationship between homeownership and period of tenure holding, which the household decided to buy a home when they are committed to remaining in a community for a long period. The stability is also associated with safety, which the area provide safety with a low crime issue is more preferable. This point also been supported by prior scholars by agreed that the households are amenable to allocate higher housing cost for a favorable neighborhood (Mariadas, Abdullah \& Abdullah, 2019; San, 2016; Thaker \& Sakaran, 2016; Zeng, 2013).

Renting cost is less than a new mortgage therefore the renting has won this point. In most housing sub-market, renters bear less housing cost than homeowners for an equivalent house (Hulse, Burke, Ralston and Stone, 2010). Accordingly, most people tend to rent due to an inadequate amount of household wealth and savings lacking (Boshoff, 2015) and therefore, renting is an alternative to homeownership. To illustrate this, most Swiss households being renters compared to in other countries and merely under $34 \%$ Swiss have the lowest homeownership in Western Europe (Bourassa and Hoesli, 2010). Furthermore, as a young cohort, most of them considered a new in the career pathway and relatively received low-moderate income. The young may not be financially stable and making buying a house a liability instead of an asset, where they may not desire to be tied down to a mortgage bond payment for the next 20 to 30 years (Boshoff, 2015). Albeit, some study in Australia proved that low-moderate income home buyers have had potential to build wealth over their homeownership but with a higher magnitude of risk of financial strain in sustaining persistent payments in the early years of mortgage (Hulse et al., 2010). This point expresses that renting provides short term commitment compared to homeownership.

Building equity is one of the primary financial opportunities of homeownership. Equity is the amount of home that one actually owns after accounting for debt, which there are two ways to build equity through the home with increasing property value or decreasing amount of debt. For instance, if the home value increases, the homeowners instantly have more 
equity. Some scholars agreed that buying a home is considered as an effective property investment (Chyi, 2013; Lim et al, 2018) as it offers the highest risk-adjusted returns (Chyi, 2013). Some postulated that a homebuyer would benefit from rises in the asset value (Reen \& Razali, 2016; Herbert, McCue and Sanchez-Moyano, 2013, if they contribute with a modest downpayment (Herbert et al., 2013). Besides that, the homebuyer could increase the investment-return of the house. Improvement on the house would have changed the capital structure would increase the house value, which it assists to raise homebuyer utilities and lower their regret from homeownership (Nwogugu, 2008). In spite of that fact, the equity doesn't grow immediately, and might experience a volatility trend over time. Prior studies have proven that house price experience volatility in developed countries (Reen \& Razali, 2016) and other studies in Australia also found that the house volatility of eight capital cities (Lee, 2009).

In other points, renting becomes preferable due to flexibility which is absent for homeownership. Especially for young professionals who are familiar with the employment changing in earlier career pathways, therefore, the rental market is preferable and might continue a stronghold. As mentioned by Hargreaves (2002) that renters tend to change to a new job as compared to homeowners who own their houses. Renting is chosen due to its flexibility to move to another place to raise a household social capital or human capital (Silver, 1988). For example, the household move to shorten travel times to work or to school and perhaps change to different neighborhood due to upgrading social structure and as well as increasing household size which result to huge and comfortable house. Figure 1.0 shows the SWOT analysis on advantages and disadvantages of buying and renting a home.

Figure 1. SWOT analysis on advantages and disadvantages of buying and renting a home

a) Buying a home

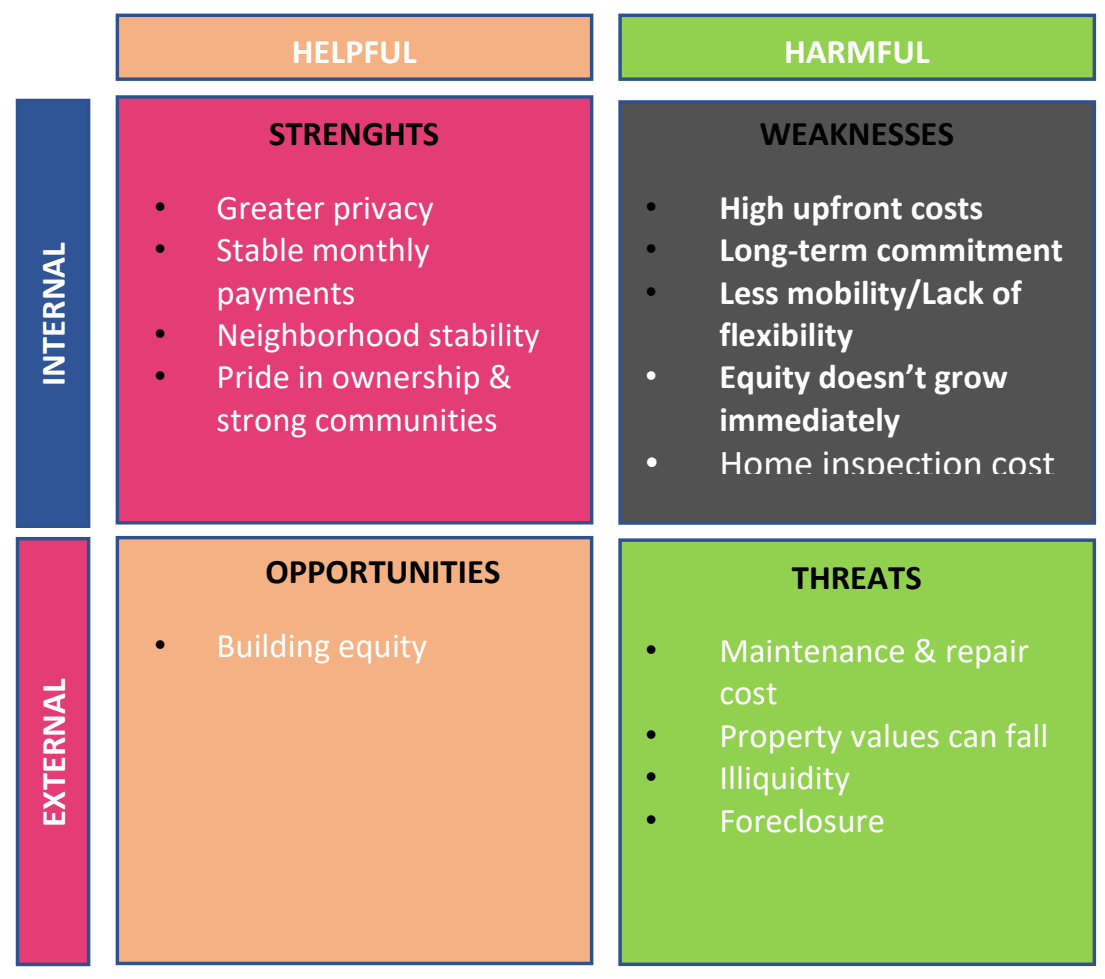


b) Renting a home

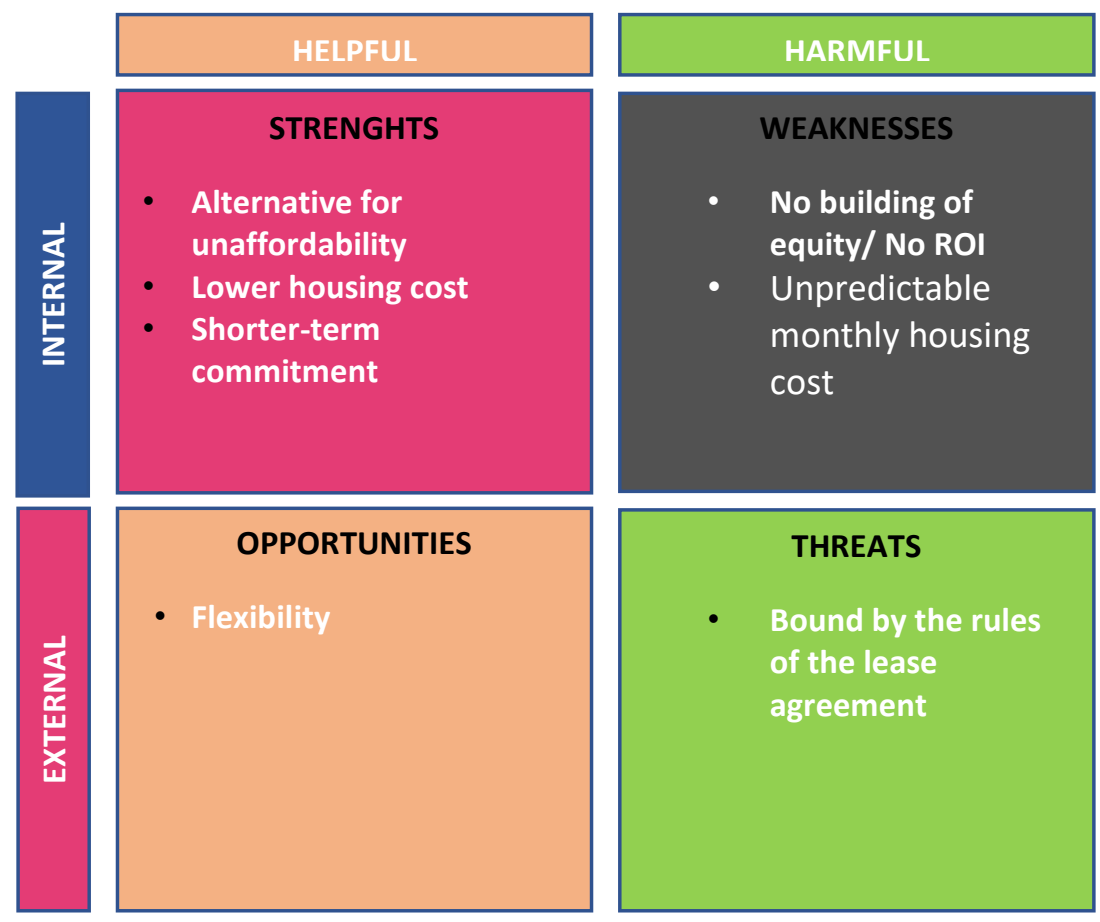

\section{2) The housing decision trend among young professionals}

The narratives analysis captures detailed individual experiences in relation to housing transitions over their life course. Accordingly, the connection between house and household is often inextricably associated with the changing of time. This analysis purposely identifies the housing decision trend among Malaysian young professionals. Firstly, most Malaysian university students lived in a hostel for the first year of studies as the university offers accommodation and only hunt for a shared rental house with high capacity in one house after turn to second years of university. Based on the interview with three of them, they mentioned that they lived with seven to ten tenants at one time in a house-sized 650 to $1000 \mathrm{sq}$. ft. At the student pathways, all of them had no comprehensive plan and never thought about homeownership for the future as they felt secured with their condition as the rental rate did not burden them.

After completing studies, they return to their parents' house (parental home) as indicated by respondent 1 (R1) or turn to the private rental market as indicated by respondent 2 and $3(R 2, R 3)$. At this stage, they were entering career pathways and preferred shared rental with only three to four tenants at one time. Referring to Figure 2.0. shows that all respondents became homeowners at the age 28 to 29 years old. From the interview, it clearly shows that most respondents chose a private rental house before they could afford to buy a house after getting married. However, a young married couple as indicated by R1, remained living in a parental home about two years plus before being homeowner. All respondents admitted that preferences for living independently but due to affordability issues, they had to parental home.

However, a parental home is not the significant reason to enable buying a house. Instead, the parental home likely has initial assistance for young professionals to manage their expenses and save for house deposit. This point agreed by R1 as mentioned that she still 
needed relying on her father's in-law assistance in getting house deposit about MYR 42,000 albeit she was a parental home after marriage.

Briefly, most young professionals were not aware of homeownership at the student pathways, albeit awareness of homeownership during student pathways is a good starting point to a literate young group on financial management including spending behaviour. Then, living in a parental home was merely an initial aid for a young married couple. Figure 2.0 shows the housing pathways of young professionals. 
Figure 2.0 : The housing pathways of young professionals

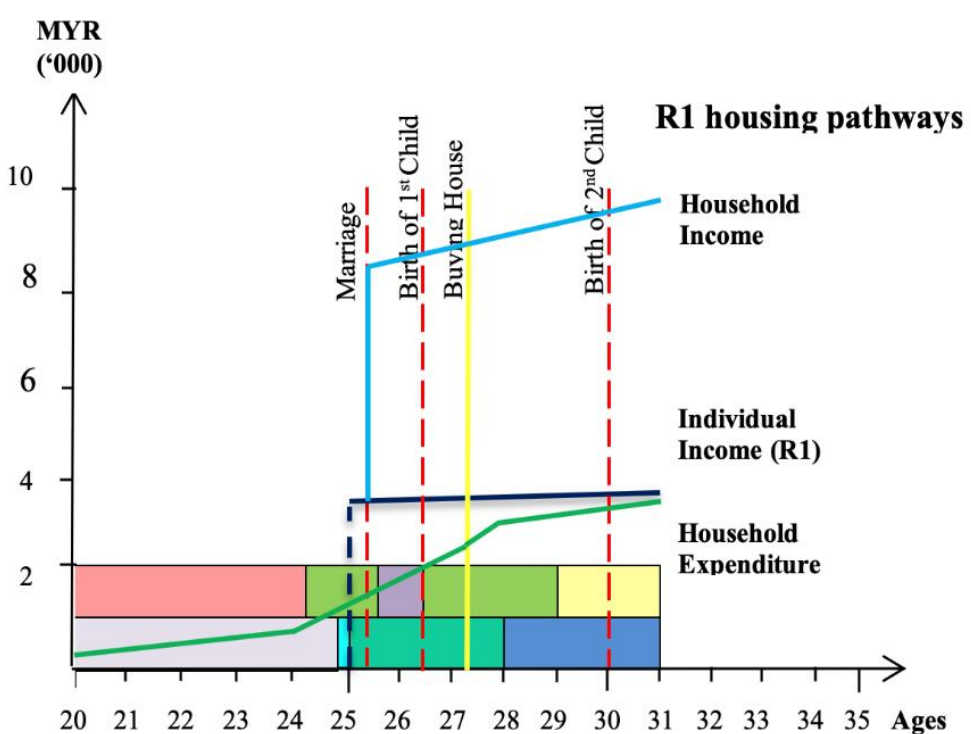

Hostel / Student Rent House

MYR

('000)

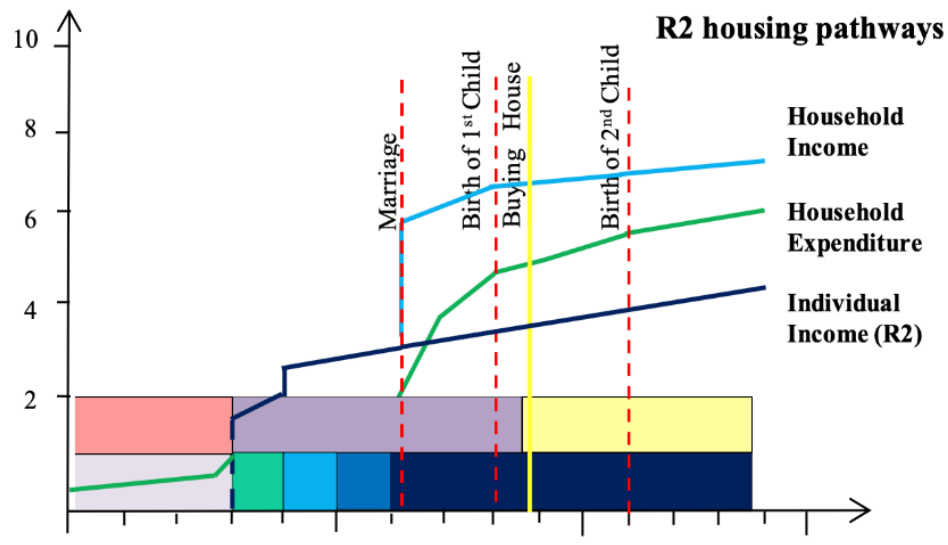

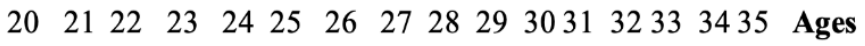

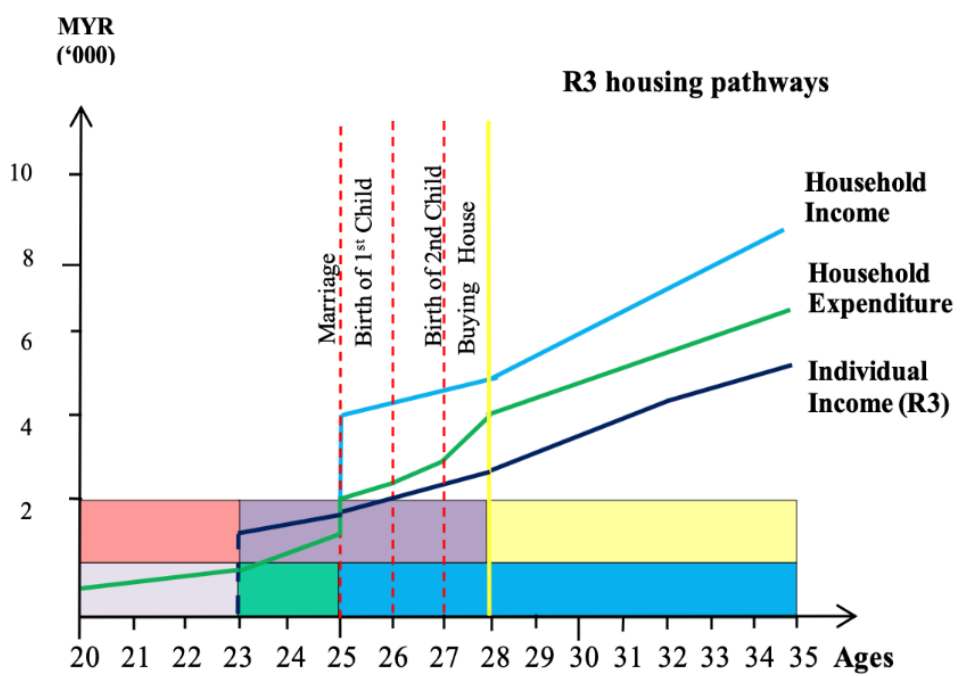




\section{Conclusion and Future Research}

Renting is always assumed as an alternative to homeownership when the household lacks affordability to buy a house in the current market as the price skyrocketed. However, renting trends seem accepted among the young cohort, which seems to have a mentality that they don't mind renting a home. Albeit homeownership is a dream for almost all Malaysian regardless of their cohort. This paper reviewed prior literature on the advantages and disadvantages of homeownership and renting. Therefore, this study suggests for the future research involving empirical results with conducting in-depth interviews among young professionals to obtain housing preferences or choice among this group. This would provide another housing decision landscape among young groups. The housing pathways of young professionals of this study, proved that this group lacks housing affordability for buying a home immediately after graduation, therefore renting becomes most preferable as well as parental home. At the age of 28 to 29 is the ideal age to be a homeowner.

\section{Corresponding Author}

Nor Suzylah Sohaimi

Department of Planning and Property Development, School of Government, College of Law, Government and International Studies, Universiti Utara Malaysia, Malaysia.

Email: suzysuhaimi@uum.edu.my

\section{References}

Bertasso, C., \& Pillay, D. (2015). The Rent vs Buy Decision of Residential Property. Accessed https://www.researchgate.net/publication/314611349_The_Rent_vs_Buy_Decision_o f_Residential_Property

Bourassa, S. C., \& Hoesli, M. (2010). Why do the Swiss rent?. The Journal of Real Estate Finance and Economics, 40(3), 286-309.

Chyi, L. L. (2013). Housing in Malaysia as a portfolio investment. International Journal of Housing Markets and Analysis, 1(4), 352-361.

Fraser, W. D. (1992). Principles of Property Investment and Pricing. London: The Macmillan Press LTD.

Hargreaves, B. (2002). TO RENT OR BUY?: THAT IS THE QUESTION. New Zealand Property Journal, 1-17. [Online] Available from: http://www.prres.net/Papers/ Hargreaves_Rent_or_Buy_That_is_the_question.pdf [Accessed: 2014-07-29].

Herbert, C. E., McCue, D. T., \& Sanchez-Moyano, R. (2013). Is homeownership still an effective means of building wealth for low-income and minority households?(Was it ever?). Homeownership Built to Last.

Hulse, K., Burke, T., Ralston, L., \& Stone, W. (2010). The benefits and risks of home ownership for low-moderate income households. AHURI Final Report, 154.

Jayantha, W. M., and Ming, J. L. (2016). Buyers' property asset purchase decisions: an empirical study on the high-end residential property market in Hong Kong. International Journal of Strategic Property Management, 20(1), 1-16.

San, C. (2016). Attributes influencing home buyers' purchase decision: A study of residential property in Setia Alam (Master's thesis, University Tunku Abdul Rahman, Kuala Lumpur). 
Silver, S. D. (1988). Interdependencies in social and economic decision making: a conditional logit model of the joint homeownership-mobility decision. Journal of consumer research, 15(2), 234-242.

Sohaimi, N. S., Abdullah, A., \& Shuid, S. (2017). A Review on Housing Pathways Approach for Young Professionals Housing Affordability. International Journal of Academic Research in Business and Social Sciences, 7(6), 2222-6990.

Khazanah Research Institute. (2015). Making housing affordable. Kuala Lumpur.

Lee, C. L. (2009). Housing price volatility and its determinants. International Journal of Housing Markets and Analysis, 2(3), 293-308.

Lim, X. Y., Olanrewaju, A. L., Tan, S. Y., \& Lee, J. E. (2018). Factors determining the demand for affordable housing. Planning Malaysia Journal, 16(6), 751.

Li, Y., \& Wen, D. (2018). The Rental Right Policy Impact on Young People Rent and Purchase Intention, 2018 IEEE/ACIS 17th International Conference on Computer and Information Science (ICIS), Singapore.

Ling, C. S., Almeida, S. J., \& Wei, H. S. (2017). Affordable housing: Challenges and the way forward. BNM Quarterly Bulletin: Box Article, Fourth Quarter, 19-26.

Reen, T. A., \& Razali, M. N. (2016). The dynamics of house price volatility in Malaysia. Journal of Technology Management and Business, 3(2).

Rohe, W. M., \& Stewart, L. S. (1996). Homeownership and neighborhood stability. Housing Policy Debate, 7(1), 37-81.

Sean, S., and Hong. T. (2014). Factors affecting the purchase decision of investors in the residential property market in Malaysia. Journal of Surveying, Construction and Property (JSCP), 5(2), 1985-7527.

Mariadas, P. A., Abdullah, H., \& Abdullah, N. (2019). Factors influencing the first home purchase decision of middle-income earners (M40) in Selangor, Malaysia. e-Bnagi, 16(1)

McCabe, B. J. (2016). No place like home: Wealth, community, and the politics of homeownership. Oxford University Press.

Nwogugu, M. (2008). On the Choice Between Renting and Home-Ownership in the Housing Industry. Developments in Chaos and Complexity Research, 231.

Tan, T. H., 2014. Determinates of homeownership in Malaysia. Habitat Internatinal.

Thaker, H., and Sakaran, K. (2016). Prioritisation of key attributes influencing the decision to purchase a residential property in Malaysia. International Journal of Housing Markets and Analysis, 9(4), 446-467.

Zeng, R. (2013). Attributes Influencing Home Buyers' Purchase Decisions: A Quantitative Study of the Wuhan Residential Housing Market. DBA thesis, Southern Cross University, Lismore NSW. 